\title{
A VÁSÁRLÓI ÉRTÉKEK ÉS A GYENGE ELKÖTELEZŐDÉSEK AZ ÉLELMISZERPIACON
}

\author{
-
VALUE DIMENSIONS OF CONSUMERS AND THE WEAK COMMITMENT
ON THE FOOD MARKET \\ MIKLÓS, ILONA

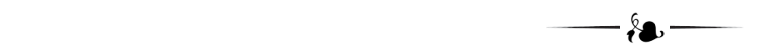 \\ Budapesti Corvinus Egyetem, Gazdálkodástudományi Kar, Vállalatgazdaságtan Intézet, Logisztika és Ellátási Lánc Menedzsment Tanszék \\ (Corvinus University of Budapest, Faculty of Business Administration, Institute of Business Economics, \\ Department of Logistics and Supply Chain Management) \\ Budapest H-1093 Fóvám tér 8. \\ email: ilona.miklos@uni-corvinus.hu
}

\begin{abstract}
g This paper aims to present the value dimensions of the protection of the domestic food market by analyzing the consumer value of the European Union geographical indications of origin (which defines certain foods as national ownership). The research covers the relationship between contemporary food policy and sociological values of consumers, including identity, credibility and culture, as well as the complexity of globalization. Although food plays a central role in maintaining human life, consumers generally know very little about where the purchased product comes from, the environmental and social costs involved, as monitoring the environmental impacts of the entire global food system is complex and a complex process. For a customer to understand what steps need to be taken to ensure the sustainability of the system and launch a change needs a huge amount of knowledge. This study applied face consciousness as a sustainability is a cultural dimension to explore the cultural impact on consumers' decision-making styles. The paper is used empirical research multi-dimensional scaling to find out what some food products become known to domestic customers while other products do not. The results found the gap that the Hungarians are rather risk-averse customers than health conscious which does not fulfil the requirement of the long-term sustainability of the nation.
\end{abstract}

KuLCSSZAVAK: társadalmi értékek, fogyasztói észlelés, fenntartható fejlődés

JEL-KóDoK (JEL CODES): A13 B55, D18

DOI: https://doi.org/10.20494/TM/6/1/2

\section{BEVEZETÉS - INTRODUCTION}

Az Európai Unió (EU) egyszerre tesz erőfeszítéseket a nemzetközösségek valamint a nemzetiségek közötti önmegvalósítására, a kivételesség alapjainak megerősítésére (BRUBAKER, 1996; CALHOUN, 2007; KEATING, 2004). Miközben az unió a szimbolikus egység építésére fókuszál a közbeszéd és a társadalmi gyakorlat kiépítése révén (BILLIG, 1995), addig alig született elemzés annak megfogalmazására, hogy
KEYWORDS: social values, consumer protection, sustainable development

vajon az eredetmegjelölési címkékhez kapcsolódó intézményi stratégiák és a hozzá kapcsolódó vásárlói legitimálódtak-e a hazai gyakorlatban. A cikk primer kutatása arra keresett választ, hogy miképpen jellemezhető a magyar vásárlói profil, milyen manifeszt és látens értékek mentén húzódó törésvonalak befolyásolják a földrajzi árujelzős termékek (nem) vásárlását Magyarországon.

Jelen cikk a fogyasztói megítélésével kapcsolatban készült korábbi hazai kutatások 
eredményeiból indul ki, amelyek azzal foglalkoznak, hogy a hazai uniós árujelzővel ellátott termékek vajon ismertek-e a magyar fogyasztók körében. Meg tudják-e különböztetni a magyar fogyasztók más, minőségtanúsítványhoz kapcsolható érvényes védjegyektôl (POPOVICS, 2009; PANYOR, 2007; SZAKÁLY et al., 2010; JUHÁSZ, 2005)? A korábbi tanulmányok megállapításai szerint a magyar vásárlók csak a hagyomány kötelékében ismerik fel a földrajzi árujelzővel ellátott élelmiszereket (POPOVICS, 2009), mert az uniós védjegyek elvesznek a magyar minőségtanúsítványok tengerében (SZAKÁLY et al., 2010), és ez a döntési zavar okozza az egyes árujelzők nem észlelését, sikertelenségét.

A cikk ontológiai kiindulópontja, hogy minden étel jelentéssel, vagyis értékkel bír. Az étel földrajzi eredetének ismerete hozzájárul a termék gazdasági versenyképessége mellett annak környezeti és társadalmi fenntarthatósághoz is. A vásárló számára az élelmiszer lokációjának ismerete biztosítja a termelés és a fogyasztás közötti útvonal átjárhatóságát. Egy élelmiszertermék eredetének ismerete, illetve értékének megtartása hosszútávú gondolkodással a fenntarthatóságot jelentheti a jelen és jövő generációk számára.

Egy termék számára fontos, hogy egy márka kialakítása során milyen szempontok/értékek köré építhető fel marketingstratégia. A vásárlói tudatosság és a fogyasztói felelősség hatékony eszköz lehet a gyengébb minőségü élelmiszerek visszaszorításában. A vásárlói profil megkülönböztetésére az eddig megismert szakirodalomban leggyakrabban a külső tényezők vizsgálatát (ár, idő, demográfia) választották a kutatók. A kérdés arra irányult, hogy magyar vásárlók tudatosak-e a vásárlásaik során.

\section{Elméleti Keret - Theoretical} FRAMEWORK

\subsection{Beágyazottság - Embeddedness}

A dolgozat egyrészt interpretatív szemléletből, Polányi és Granovetter beágyazottság fogalmából indul ki, amely szerint a gazdasági cselekvés „beágyazódott a konkrét társadalmi kapcsolatok rendszereibe” (GRANOVETTER,
1983). A gazdasági eredményeket a strukturális elemek magyarázzák, vagyis a közösségi hálózatok tulajdonságai (GRANOVETTER, 1983) és piaci gyakorlata megkönnyíti a kollektív fellépést. Beágyazottság kettőssége GRANOVETTER (1992) számára relációs, illetve strukturális vonatkozásaiban ragadható meg, GRANOVETTER elképzelése szerint az erős és gyenge beágyazottság fogalmai a gazdaság társadalmi függőségének súlyával együtt változik. Álláspontját azzal indokolja, hogy egyrészt a gazdasági célok követése általában nem-gazdasági célok (hatalom, presztízs, társadalmi státusz) követésével kapcsolódik össze. Másrészt a gazdasági cselekvést nem lehet egyéni motívumokkal magyarázni, mert társadalmilag meghatározott, harmadrészt a gazdasági intézmények nem automatikusan, hanem inkább társadalmilag formálódnak. LEWIS és BRIDGER (2000) szerint a felgyorsult igények mellett a bizalom kiemelten fontos szemponttá vált, ezért a hitelesség megteremtése a legfóbb cél azokon a pontokon, ahol a vásárló kockázatot észlel, hiszen amennyiben kialakul a bizalom, leegyszerűsíthető a vásárlási döntés. GOODMAN (2003) az élelmiszeripari ágazatban a 20. század végére bekövetkezett „minőségi fordulatot” (quality turn) három koncepcióra összpontosította: a bizalomra, a beágyazottságra és a helyre. Elgondolása szerint az élelmiszerekkel kapcsolatos kérdések etikai és politikai mechanizmusok mentén való vizsgálatával, a fogyasztási magatartás nem csupán gazdasági, hanem társadalmilag felelős megközelítésekkel is értelmezhetővé vált.

\subsection{Földrajzi jelölés mint jogi érték - The Geographical Indication as Legal Value}

Az EU élelmiszer minőségről való vitája 1985ben az ún. Zöld Könyv néven kiadott (Green Paper) és a 1988-ban megjelent a vidéki társadalom jövőjéről szóló közleményig (Communication on "The Future of Rural Society") nyúlik vissza, amely az élelmiszer minőségéről, a környezetről és az ökoszisztéma megőrzéséról szól, amelyben az agrárium kiemelt felelősséggel bír. A földrajzi árujelzők elfogadásával kapcsolatban kialakult szakmai vita rámutatott 
az északi és a déli tagállamok eltérő közösségi sémáira, ugyanis északon, szemben a déliekkel, inkább védjegyek oltalmának kívántak elsőbbséget adni, sem mint a földrajzi árujelzőknek (PALLÓNÉ, 2003).

A földrajzi árujelző, mint jogi szabályozással bíró szellemi tulajdon, a szubszidiaritás elve miatt az Európai Unióról szóló szerződés 5. cikke miatt az uniós jogi szabályozás és a tagállamok megvalósításának dilemmáját hordozza magában.

Az unión belüli hatáskörök gyakorlását a szubszidiaritás elve határozza meg, amely elsőként tagállami szinten a döntési és cselekvési képességet védelmezi, másodsorban viszont lehetővé teszi az uniós szintű cselekvést. Az uniós áruvédjegy elfogadásának, értékeinek felismerése és múködtetése a tagállamok közösségén belül eltérő, ahogy a közjó értékei feletti gondolkodásuk sem azonos feltehetőleg. $\mathrm{Az}$ uniós földrajzi árujelző értékeinek és ismertségének vizsgálata az egységes értékekről való gondolkodás vizsgálatát is jelenti.

LANGINIER és BABCOCK (2008) a földrajzi árujelzők termékeire „klubtárgyakként”, azaz olyan közjó típusokként tekintenek, amelyek a tényleges klubokhoz hasonlóan, egyesek kizárhatóak. A klubtagsággal járó előnyök minden felhasználó számára ugyanúgy élvezhetőek, amíg nem érik el a piaci zsúfoltságot, és a túlzott fogyasztói igények miatt rivalizáló árukká nem válnak.

\subsection{Az élelmiszer egydimenziós kon- cepciói - One-Dimensional Conceptions of Food}

Az ételt, az élelmiszertermelés összefüggései alapján elsőként a mezőgazdasági és gazdálkodási rendszerekbe való beilleszthetőség alapján vizsgálták (SPEDDING, 1996). Az élelmiszerrendszerek kutatásának első hulláma történelmileg a vidékkel kapcsolatos tudományágak (rural science) tanulmányai adtak alapot. A klasszikus, kizárólag gazdasági megközelítésű un. „egydimenziós” koncepciók már nem voltak alkalmasak az 1980-as években fellépő új gazdasági és politikai kihívások megválaszo- lására (FRIEDMANN 1993; FRIEDMANN és MCMICHAEL 1989). Az élelmiszerrendszer elméleti paradigmaváltását ezért egyrészt gazdasági, másrészt társadalmi szükségletek teremtették meg.

\subsubsection{Az élelmiszer kontextusfüggósége \\ - The Context Dependency of Food}

FRIEDMANN (1993) szerint az ételról pusztán gazdasági szemléletról való gondolkodást szükségszerúen írta felül az élelmiszerek vizsgálatában a különböző kontextusalapú: kultúra, történelem, szociológia és marketing szemléletú megközelítések. A kontextusalapú megközelítésben már erős fenomenológiai befolyás alatt vizsgálják az élelmiszer-fogyasztás szociokulturális hátterét és az élelmiszerek szimbolikus jelentésében bekövetkező változásokat.

FIDDES (1990) szerint az élelmiszerrendszer és az élelmiszer-fogyasztás vizsgálata leginkább arról szól, hogy az élelmiszer, a kultúra és a politika a szétválasztásuk ellenére hogyan kapcsolódik újra egymáshoz az újjászerveződő társadalmakban. Fiddes szerint az élelmiszerválasztás kulturális és környezeti következményei egyéni szinten a bizalom és a kockázat fogalmai mentén illeszkednek a modern életbe. Fiddes kontextusalapú vizsgálatában az a fő kérdés, hogy melyek azok a kulcsfontosságú ötletek, amelyek megváltoztatták és hatással vannak a helyi fogyasztási szokásokra. Fiddes felfogásában modern életre jellemző egészségtudatosság és az egészségre vonatkozó aggodalmak, mint racionálisan kitüzött célok a mindennapi életben napjainkban maguk mögé szorítják a hagyományos kulturális hiedelmeket.

A kontextusfüggőség másik kiemelkedő képviselője APPADURAI (1986), aki antropológusként gondolta újra az élelmiszer szerepét. A megállapítása szerint a késő- vagy posztmodern társadalmakban a földrajz már elvesztette a közösség és az identitás kialakító szerepét, ami azt jelenti, hogy a média révén erős érzelmi kötődések és bizalmi viszonyok alakíthatók ki akár földrajzi távolságtól mentesen. 


\subsubsection{Az élelmiszer sokdimenziós megközelítése - The Multidimensional Approach of Food}

Az élelmiszerről való rendszerszemléletủ kutatásokban a harmadik fontos hatást a környezetvédelmi szemlélet és az erőforrások végessége miatti aggodalom (DALY és COBB, 1989) megjelenése jelentette a tudományos életben. Az élelmiszerrendszeren belüli és a külső környezeti változások kölcsönhatásaival, reakcióival (LIVERMAN és KAPADIA, 2010) kapcsolatos vizsgálatok a mezőgazdasági rendszerben való gondolkodás kitágításához és az élelmiszer szerepének átgondolásához és átalakulásához vezettek (FOLEY et al., 2011). ERICKSEN (2008) nem egyoldalúan, hanem hármas megközelítéssel vizsgálja az élelmiszerrendszert, mint társadalmi-ökológiai rendszereket (Social-Economy-System (SES)), ahol az élelmiszerrendszer és a globális környezeti változások többszörös interakcióban állnak egymással. Ezek kölcsönhatásai által érintett legfontosabb társadalmi eredmények egyidejúleg vizsgálatába viszont már bekerült az élelmiszerbiztonság, az ökoszisztéma-szolgáltatások és a szociális jólét fogalma is. Ebből a nézőpontból az étel, az emberi és a biofizikai környezet közötti összekapcsolódás az élelmiszertermelés és fogyasztás, valamint azok kimeneteleinek összetett vizsgálata alapján ragadható meg, a szereplők kölcsönös egymásra hatásának vizsgálatával.

\section{4. Értékrendszer - Value System}

Az értékpreferenciák a cselekedeteket és a döntéseket is alakító tényezőkre, ezen kívül a magatartásminták közüli választásokra is hatást gyakorolnak (FEATHER et al., 1999). Az értékek rendszerszerüen és hierarchikusan szerveződnek, az értékekből kialakított struktúrák az emberi viszonyok mentén válnak értékké és az elfogadott vagy elutasított értékek azok, amelyek leírják és magyarázzák a világot, amelyben az egyén feletti értékrendszerek és értéktudat közös történelmi sors és cselekvés szerves részét képezik.

\subsection{Az észlelés különbözőségei - Differences of Perception}

Az emberek ugyanazt a dolgot nagyon különböző módon érzékelhetik, mivel ugyanaz az esemény több érzékszervvel, különböző érzékelésen keresztül érzékelhető.

KOLOS (1997) rámutat arra, hogy fontos a fogyasztói kockázatészlelés és annak kezelése. Minél nagyobb az eltérés az elvárt és az észlelt minőség között, annál nagyobb a fogyasztó elégedetlensége. Ez azért is fontos, mert a fogyasztó elégedettségének mértéke határozza meg a vásárlás utáni magatartását.

HOFMEISTER-TÓTH (2003) szerint a fogyasztó a vásárlás során számos döntéshozatallal és kockázattal kerül szembe. A vásárlási döntést megelőzve, mások attitűdjén kívül más, váratlan események is hatással vannak a vásárlóra. A vásárló által észlelt kockázat mértéke szubjektív, ami függ a vásárló személyiségétől, az adott kultúrától, az adott vásárlási szituációtól, ahol a tranzakció létrejött és amely során a termék vagy szolgáltatás jellege és ára viszonyításra került.

Az észlelések különbözőségét már az észlelés elején a befogadóban lévő prekoncepció hozza létre. Az észlelés nem független attól a világképtől, amely élmények, tapasztalatok, hiedelmek, értékek, attitűdök köré szerveződik (BAKACSI, 2010).

\subsection{Az észlelt értéket befolyásoló ténye- zók - Factors Affecting the Perceived Value}

A fogyasztók annak alapján döntenek egy termék megvásárlásáról, hogy miképpen ítélik meg annak hasznosságát, illetve, hogy megítélésük szerint, a versenytárs által biztosított helyettesítő termékek hasznossága és ára milyen előnyökkel és kockázatokkal járhat.

Az értékvizsgálatokat felölelő szakirodalom különbséget tesz a tényleges (objektív) és a vevő által felismert és elfogadott érték (hasznosság) között, amikor vevő nem a tényleges, objektív érték alapján dönt, hanem az elvárásai, emocionális benyomásai alapján. Az elfogadott érték 
tehát nem más, mint a vevőnek a termék hasznosságáról alkotott benyomásainak összessége (NILSON, 1992).

A márkaérték mérésével és nyomonkövetésével lehetőség adódik a márkák mögött meghúzódó értékeket mérni. A márka értékének mérésével két vállalati terület foglalkozik részletesebben: a pénzügyi érték mérése és a fogyasztói márkaérték mérése. Egy élelmiszertermék esetén megfogható fizikai tulajdonságainak összhangban kell lenniük az észlelés lélektani szintjén azonosított hagyomány érzettel (TREGEAR, 1999).

HOFMEISTER-TÓTH (2003) a márkákat értékelő kritériumok fogalmát olyan tulajdonságokként határozza meg, amelyeket a vásárló keres egy bizonyos fogyasztói probléma megoldására. Ilyen értékelő kritérium lehet az ár, a minőség, a teljesítmény, a stílus, az íz, a presztízs stb.

HOFMEISTER-TÓTH és munkatársai (2003) megközelítése alapján nemcsak az objektív, hanem négy szubjektív tényező is hatással van az értékelési folyamatokra., úgy mint észlelés, meggyőződés, attitűd és szándék. Az észlelés a termék minőségén és a promóciós üzenetek mellett személyes tényezőktől is függ, hiszen az észlelést az egyén szükséglete, múltbeli tapasztalata, tudása, motivációja, személyisége és kulturális környezete is befolyásolja. Nem elhanyagolható tényező azonban a vásárlás kockázatának észlelése mellett az elégedettség vagy az elégedetlenség észlelése sem, amelyek a vásárlási döntésekre szintén hatással vannak.

Látható, hogy a fogyasztói döntésekben az objektivitás és a racionalitás ritkán érvényesül teljesen, hiszen szubjektív tényezők hatására sérül a teljes racionalitás (BAUER és BERÁCS, 2006).

\subsubsection{A fogyasztói környezettudatosság - Environmental Awareness of the Consumer}

A fenntartható fejlődés (sustainable development), mint a vásárlási folyamatokat meghatározó külső lehetőség, fogalma az 1980-as években jelent meg először a szakirodalomban, majd az ENSZ 1987. évi ún. Brundtland Jelentésével került be a köztudatba. A fenntartható fejlődés olyan folyamat, amely „kielégíti a jelen generáció szükségleteit anélkül, hogy veszélyeztetné a jövő generációk esélyeit arra, hogy ők is kielégíthessék szükségleteiket" (BRUNDTLAND, 1988).

SCHALTEGGER et al. (2003) szerint a fenntarthatóság a természeti, gazdasági, humán, és társadalmi erőforrások hosszú távú megőrzését jelenti, a fenntarthatósági indikátorok pedig ezen erőforrások alakulását jellemzik. A fenntarthatósági indikátorok mérése a hosszú távú folyamatok vizsgálatában segítheti a lokális, regionális vagy globális ökoszisztémában, gazdaságban, illetve közösségben megjelenő nemkívánatos jelenségek felismerését. A termelési folyamatokban létrejövő változások nyomon követése és a társadalmi beavatkozások, intézkedések hatásainak vizsgálata során a gazdasági, társadalmi és környezeti dimenziók egyidejű megvalósulása alkotja a fenntartható fejlődés alapját, és bármelyik elhanyagolása veszélyezteti a szervezetek fennmaradását (CSUTORA és KEREKES, 2004).

KOTLER (1998) a társadalmi és környezeti felelősséget lefedő marketinget társadalmi marketingként határozta meg. Míg KOTLER (1998) a gazdasági hatékonyságot magától érthetődnek tekinti, addig a környezettudatos marketing a vállalatok és a környezeti, illetve társadalmi szempontból is tudatos kereslettel rendelkező piacok közötti kapcsolatok kiépítésében játszik fontos szerepet.

NEMCSICSNÉ ZSÓKA (2005) szerint az ökológiai tudás és a környezeti értékek kölcsönösen hatnak egymásra, mivel az ökológiai tudás és az értékek együttesen befolyásolnak konkrét helyzeteket és attitüdöket, amelyek meghatározzák a cselekvési hajlandóságot, végül a cselekvést.

\section{7. Észlelési térkép és multidimenzio- nális skálázás - Perception Map and Multidimensional Scaling}

A termék hasznossága illeszkedik a vásárlói értékek sorrendiségéhez is. A termékpozícionálás az a tevékenység, amelynek során a vállalat megkísérli elhelyezni az adott terméket a vevők tudatában. Ahhoz, hogy a termékpozicionálás sikeres legyen egyrészt (1) fontos megismerni, hogy a vásárlók, milyen dimenziók alapján kü- 
lönböztetik meg a piacon versenyző termékeket, másrészt (2), hogy miképpen „észlelik” a vevők ezeket a termékeket.

Észlelési térkép a fogyasztók márkákra, termékekre vagy cégekre vonatkozó észleléseinek grafikus megjelenítését jelenti (LEHOTA, 2001). Az észlelési térkép segít abban, hogy a piaci rejtett tartalmak, tendenciák, meghatározó kapcsolódások révén megbízható képet adjon a fogyasztók termék érzékeléséről. Az észlelési térkép vizuálisan mutatja be azt a piaci struktúrát, amelyben a termékek versenyeznek. Az észlelési térképen jellemzően két dimenzióban ábrázolható a piaci struktúra, amelyen a piacon lévő termékeket a két dimenzió koordinátái által meghatározott pontokat jelölik. A vásárlók által észlelt hasonlóságok alapján kerül összehasonlításra a közöttük kialakuló preferencia-sorrend a sokdimenziós skálázás módszerével észlelési térképet lehet készíteni (LEHOTA, 2001).

\section{ANYAg ÉS MÓDSZER - MATERIAL AND METHOD}

A cikk, módszertanilag abból indul ki, hogy az észlelés egyfajta mentális térkép a környezetről, ami szubjektív értékítélet és szempontok szerint torzít, és a környezet használata során folyamatosan alakul.

A cikk a Qualtrics online rendszer segítségével összeállított kérdőív eredményei alapján a 2018. május és június hónapokban megkérdezett, nem reprezentatív 196 fós minta adatait dolgozta fel többváltozós statisztikai elemzéssel, az SPSS 22.o program segítségével.

A cikk primer kutatásában a sokdimenziós skálázás (MDS) a faktoranalízissel való öszszehasonlítás után azért került kiválasztásra, mert míg a faktoranalízis vizsgálatban sokféle változó bevonható és az egyes faktorok lineáris kombinációjára épül, addig az MDS számára speciálisabb távolság- vagy hasonlóság jellegü adatokra van szükség és pontos hasonlósági mérték mellett az MDS jobb eredményt ad (KRUSHKAL és WISH, 1978; YOUNG és HAMER, 1987; FÜSTÖS és KOVÁCS, 1989).
Az MDS az értékek egy halmazát a térben elhelyezett pontok segítségével reprezentálja, ahol a pontok közötti távolság mutatja a termékek közötti hasonlóság mértékét. A cikkben az MDS módszernél az ordinális modell tűnt helytállónak, mivel a változók ordinálisak, és ezért az eljárás is nem-metrikus.

\section{EREDMÉNYEK - RESULTS}

Az élelmiszer észlelésével kapcsolatos értékek feltárása és a vásárlói profilok megkülönböztetés a kérdőívben 20 dichotóm változóval, 7 fokú ordinális skálán mért descriptive mean válaszok alapján történt (1. táblázat).

A válaszadók igen magas átlaggal $(6,08)$ tapasztalt vásárlónak tartják magukat. A válaszadók számára az egészségtudatosság $(5,07)$ a második legfontosabb érték, míg a címkék összetevői és a szavatossági idő alapján való döntés nem jelent prioritást a megadott szempontokban. A visszajelzések alapján a termékválasztásnál a vásárlók számára az ország eredete $(4,85)$ fontosabb értéket jelent, mint a termék ára $(4,81)$, ami a fókuszcsoportban a minőségi élelmiszerek árazásával kapcsolatos fókuszcsoportos eredményeket igazolják viszsza.

A válaszadók másik végletét az a csoport alkotja, akik alig vagy nem foglalkoznak élelmiszervásárlással, illetve az online vásárlást részesíti előnyben (2. táblázat).

Összességében az tűnik ki az élelmiszerek vásárlói profil adataiból, hogy az értékek egyik pólusán a magukat tapasztaltnak tartó, egészségtudatos és kevésbé árérzékenyek, míg a másik oldalon a rutinból vagy presztízs alapján vásárlók állnak. A vásárlói profil értékelése MDS vizsgálattal a leggyakrabban választott típusok szempontjából való fontosság alapján történt mivel a descriptive leírás az előzőekben nem adott elegendő információt. Az MDS módszer közvetett információk figyelembevételével alkalmas arra, hogy az értékek (objektumok) között valamilyen módon megmért különbözőségeket, eltéréseket, de a köztük levő hasonlóságokat is kimutassa. 
A kutatásnál felhasznált mérési skálák a vásárlói profil feltárásakor (Scales Used for Research to Develop Customer's Profile)

\begin{tabular}{|c|c|c|c|c|c|}
\hline \multicolumn{2}{|c|}{$\begin{array}{c}\text { Kérdőív kód } \\
\text { (Questionnaire code) }\end{array}$} & \multirow{2}{*}{$\begin{array}{l}\quad \begin{array}{c}\text { Állítás } \\
\text { (Statement) }\end{array} \\
\text { A következő kérdés- } \\
\text { nél arra vagyunk } \\
\text { kíváncsiak, hogy me- } \\
\text { lyik állítás jellemző } \\
\text { Önre élelmiszervá- } \\
\text { sárláskor } \\
\text { (In the next question, } \\
\text { we are curious which } \\
\text { statement is typical } \\
\text { when you buy food) }\end{array}$} & \multirow[b]{2}{*}{\begin{tabular}{l}
\multicolumn{1}{c}{$\begin{array}{c}\text { Változat } \\
\text { (Variant) }\end{array}$} \\
1-20 ig állítás 1-7-ig \\
terjedő skálán (1) \\
egyáltalán nem jel- \\
lemző rám, (2) nem \\
jellemző rám, (3) \\
kissé jellemző rám, \\
(4) valamennyire \\
jellemző rám, (5) \\
(1 to 20 statements \\
on a scale of 1 to 7 \\
(1) not typical of me \\
at all, (2) not typical \\
of me, (3) slightly \\
typical of me, (4) \\
somewhat typical \\
of me, (5) typical of \\
me, (6) very typical \\
of me)
\end{tabular}} & \multirow{2}{*}{$\begin{array}{c}\begin{array}{c}\text { Mérési szint } \\
\text { (Measurement } \\
\text { scales) }\end{array} \\
\begin{array}{l}\text { Ordinális skála } \\
\text { (Ordinal scale) }\end{array}\end{array}$} & \multirow{2}{*}{$\begin{array}{c}\begin{array}{c}\text { Módszer } \\
\text { (Methodology) }\end{array} \\
\text { MDS ALSCAL }\end{array}$} \\
\hline P1-P1_20 & $\begin{array}{l}\text { Vásárlói } \\
\text { profil } \\
\text { (Customer's } \\
\text { profile) }\end{array}$ & & & & \\
\hline P2_1--P2_10 & $\begin{array}{l}\text { Vásárlói } \\
\text { profil } \\
\text { (Customer's } \\
\text { profile) }\end{array}$ & $\begin{array}{l}\text { A következő kérdés- } \\
\text { nél arra vagyunk } \\
\text { kíváncsiak, hogy me- } \\
\text { lyik állítás jellemző } \\
\text { Önre élelmiszervá- } \\
\text { sárláskor } \\
\text { (In the next question, } \\
\text { we are curious which } \\
\text { statement is typical } \\
\text { when you are buying } \\
\text { food) }\end{array}$ & $\begin{array}{l}\text { 1-10 ig állítás közül } \\
\text { saját sorrendet ál- } \\
\text { lítása } \\
\text { (1 to 1o statements } \\
\text { please create } \\
\text { sequence based on } \\
\text { own preference) }\end{array}$ & $\begin{array}{l}\text { Ordinális skála } \\
\text { (Ordinal scale) }\end{array}$ & $\begin{array}{l}\text { Leíró átlagok / } \\
\text { MacQueen non- } \\
\text { hierarchikus klasz- } \\
\text { teranalízis } \\
\text { (Descriptives } \\
\text { means / } \\
\text { MacQueen non- } \\
\text { hierarchical } \\
\text { cluster analysis) }\end{array}$ \\
\hline
\end{tabular}

Forrás (Source): Saját szerkesztés (Own compilation) 
MikLós, I.

2. TÁBLÁZAT

Vásárolói profil meghatározása descriptive mean eljárással, N=175 (Customer's Profile with Descriptive Statistics, $N=175$ )

\begin{tabular}{|c|c|c|}
\hline $\begin{array}{c}\text { P1- A következő kérdésnél arra vagyunk kíváncsiak, hogy melyik állítás jellemző } \\
\text { Önre élelmiszervásárláskor (In the next questions, we are curious as to which } \\
\text { statement is typical for you when buying food) }\end{array}$ & $\begin{array}{l}\text { Átlag } \\
\text { (Mean) }\end{array}$ & $\begin{array}{l}\text { Szórás } \\
\text { (Std. } \\
\text { Deviation) }\end{array}$ \\
\hline Tapasztalt, rendszeres vásárló vagyok (I am an experienced, expat shopper) & 6,08 & 0,937 \\
\hline Egészségtudatos vásárló vagyok (I'm a health conscious customer) & 5,70 & 1,091 \\
\hline $\begin{array}{l}\text { Fontos számomra szavatossági idő a címkéken (The expiry date on the labels is important } \\
\text { for me) }\end{array}$ & 5,54 & 1,449 \\
\hline $\begin{array}{l}\text { Rendszeresen ellenőrzöm az összetevők miatt a címkéket (I regularly check labels on food } \\
\text { for ingredients) }\end{array}$ & 5,25 & 1,637 \\
\hline $\begin{array}{l}\text { Fontos számomra a származási ország feltüntetése a címkén (It is important for me to } \\
\text { indicate the country of origin on the label) }\end{array}$ & 4,85 & 1,823 \\
\hline A termék ára hatással van a vásárlásomra (The price of the product affects my purchase) & 4,81 & 1,272 \\
\hline $\begin{array}{l}\text { Rendszeresen vásárolok a helyi piacon, termelóktől (I regularly buy from the local market, } \\
\text { from producers) }\end{array}$ & 4,71 & 1,797 \\
\hline $\begin{array}{l}\text { Általában hiper- és szupermárketekben vásárolok (I usually buy in hyper-and } \\
\text { supermarkets) }\end{array}$ & 4,67 & 1,569 \\
\hline $\begin{array}{l}\text { A személyes kapcsolatokban hiszek, kis boltokban, termelőktól vásárolok (I believe in } \\
\text { personal relationships, I prefer to buy in small shops, producers) }\end{array}$ & 4,39 & 1,657 \\
\hline $\begin{array}{l}\text { A régóta piacon lévó élelmiszerekben hiszek (I believe in food with well-known and long } \\
\text { history brand) }\end{array}$ & 4,21 & 1,558 \\
\hline $\begin{array}{l}\text { Általában bio (organikus, öko) termékeket vásárolok (I usually buy organic (bio, eco) } \\
\text { products) }\end{array}$ & 3,84 & 1,744 \\
\hline $\begin{array}{l}\text { Fontos számomra a zöld tanusítvány logója a címkén (The green certificate logo on the label } \\
\text { is important to me) }\end{array}$ & 3,80 & 1,702 \\
\hline Jövedelmem nagyobb részét élelmiszerre költöm (Most of my income is spent on food) & 3,75 & 1,598 \\
\hline Elfoglalt, rutinból vásárló vagyok (I'm busy, I am a routine buyer) & 3,65 & 1,586 \\
\hline Fair trade termékeket vásárolok ( I buy Fair trade products) & 3,63 & 1,627 \\
\hline $\begin{array}{l}\text { Többnyire (glutén, laktóz stb) mentes és diétás termékeket vásárolok (I buy free from } \\
\text { (gluten, lactose, etc.) and diet products) }\end{array}$ & 3,37 & 2,085 \\
\hline $\begin{array}{l}\text { Inkább kényelmi, félkész termékeket vásárolok (I'd rather prefer the convenience and } \\
\text { ready to use products) }\end{array}$ & 2,93 & 1,530 \\
\hline $\begin{array}{l}\text { Presztízsből vásárlok dolgokat, mert megengedhetem magamnak (I buy things from prestige } \\
\text { because I can afford them ) }\end{array}$ & 2,75 & 1,642 \\
\hline Élelmiszernél az online vásárlást részesítem előnyben (For food, I prefer online shopping) & 1,97 & 1,446 \\
\hline $\begin{array}{l}\text { Nem érdekel, nem foglalkozom élelmiszervásárlással (I don't care about food, I'm not } \\
\text { dealing with buying food) }\end{array}$ & 1,56 & 1,127 \\
\hline
\end{tabular}

Forrás (Source): Saját szerkesztés (Own compilation)

Az ALSCAL hasonlósági mátrixok a hét fokozatú preferenciaskálák korrelációs mátrixából készült térképet eredményeznek (1. ábra). Ez alapján a térkép alapján az látható, hogy a vásárlók hogyan jellemezhetők egyes vásárlói döntés fontossága alapján. Azokat a döntéseket, amelyek a térképen egymáshoz közel helyezkednek el, hasonlóan értékelték. 


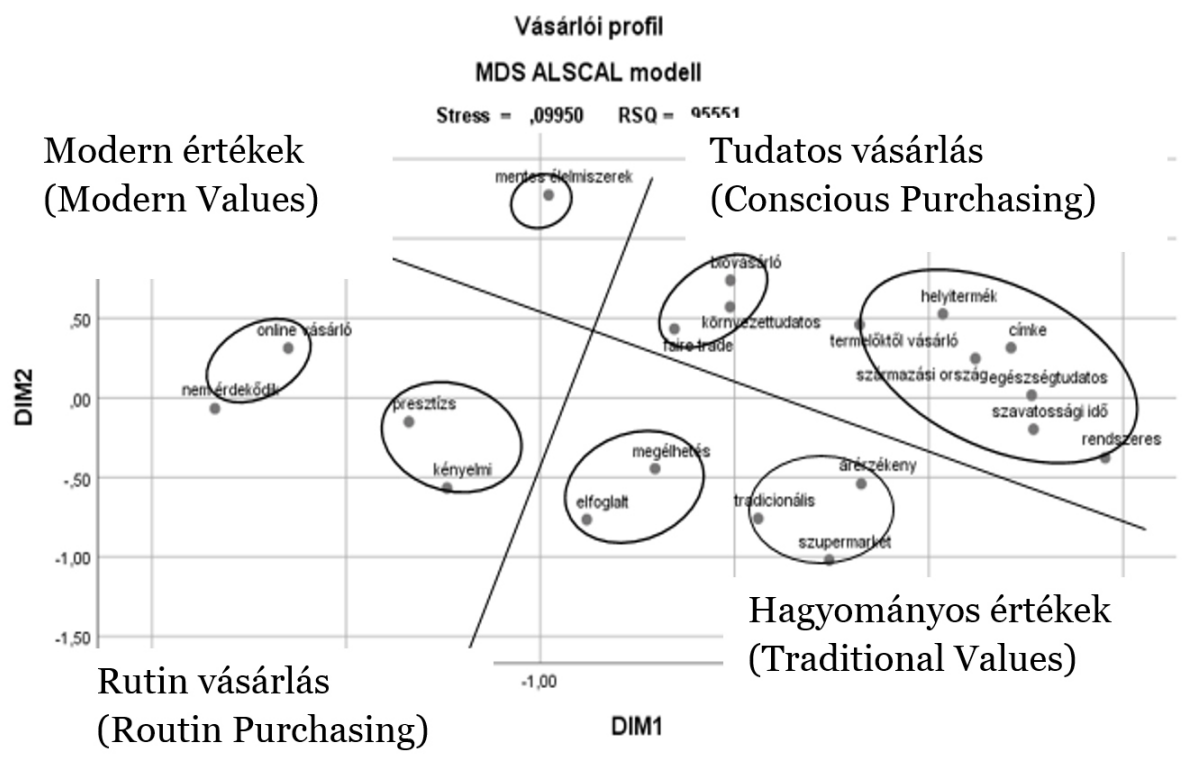

1. ÁBRA

Vásárlói profil MDS ALSCAL eljárással

FIG. 1 (Consumer Profile with MDS ALSCAL Process)

Forrás (Source): Saját szerkesztés (Own compilation)

Megjegyzés (Notes):

Modern és tudatos vásárlás értékei (Values of modern and conscious shopping): 1. minden mentes vásárlás (free from shopper)

Modern és rutin vásárlás értékei (Values of modern and routine shopping): 2. online vásárlás (online shopper); 3. étel iránt nem érdeklődő (no interest in food shopper); 4. presztízs (prestige shopping); 5. kényelmi termékek vásárlása (convenient product shopper)

Tudatos és hagyományos vásárlás értékei (Values of traditional and conscious shopping): 6. bio vásárlás (organic shopper); 7. környezettudatos vásárlás (environmental friendly); 8. méltányos kereskedelem (fair trade); 9. származási ország (made in); 10. helyi termelő (local producers); 11. helyi termék (local products); 12. szavatossági idő (expire date); 13. címke (labels); 14. egészségtudatosság (health conscious); 15. rendszeres vásárlás életmód (regular shopping)

Hagyományos és rutin vásárlás értékei: 16. elfoglalt életmód (buzy shopping); 17. árérzékeny (price conscious); 18. szupermarketeket prefereáló (supermarkets); 19. megélhetés (livelihood); 20. hagyományos értékek (traditional values)

Összességében megállapítható, hogy a vásárlói magatartás profiljai az elemzés alapján két dimenzió mentén helyezhetők el. Az első és legnagyobb magyarázóerővel rendelkező dimenzió, amelynek alapján a jelölések megkülönböztethetők, azt mutatja, hogy egyrészt létezik a „hagyományos és a modern” vásárlási értékek pólusa, illetve egy másik ellentétpár a „rutinos és a tudatos vásárlást” preferáló értékek típusai. Az előzetes tudást igénylő vásárlói döntések kifejezésének megértéséhez és a vásárlás elhozatali döntése során, a végső döntésnél szükség van bizonyos háttértudásra, úgy, mint címke értelmezése, összetevők ismerete, hatásai.
A presztízs vásárlások esetében a vásárló számára fontos értékek mentén történik a kiválasztás. A helyi, egészségtudatos termékek hasonló értékeket jelentenek azoknak a vásárlóknál, akik számára, a minőségtanusítvány és a termék származásának feltüntetése fontos. Ebben a dimenziós felbontásban a bio, környezettudatos és fair trade termékek értékeinek hasonlósága közelít egymáshoz.

Szembetűnő, a mindentől mentes (tartósító, glutén, laktóz, cukor, valamint a vegán) élelmiszereket preferáló értékek elkülönülése mindhárom csoporttól, annak ellenére, hogy szükséges a vásárlás során előzetes tudás, mind vásárlás szempontjából pedig kimondottan a 
kisebb üzletek, vagy online elérhetőség jellemzi ezt a piacot, ahol a személyes kapcsolatok, vélemények, tapasztalatok megosztása fontos vásárlók számára. Aki tudja és ismeri az alapanyag pontos eredetét, összetételét, felhasználási lehetőségeit, értékét, annak prioritást, vagyis egyfajta elköteleződést jelent a vásárlás.

Ha a döntéshozók vásárlásai során a hagyományos és a modern vásárlói értékek bináris pólusait vesszük figyelembe, az ételvásárlás döntésénél releváns értéket képviselnek a fogyasztó számára. Látható, hogy a mentes élelmiszer preferenciája időt és energiát igényel, viszont ezzel szemben helyezkednek el a rutin vásárlások értékei, amelyek jellemzően időérzékeny fogyasztót sejtetnek. Az egyedi, különleges élelmiszerek vásárlási szokásai valamint a hagyományos, vagy a mentes (free from) élelmiszerekhez kapcsolódó vásárlási szokások élesen elkülönülnek az online vásárlás kategóriájától.

Összefoglalásként a válaszadók vásárlói profil értékei mentén, az élelmiszervásárlói preferenciák Magyarországon, a nem reprezentatív minta alapján, elmondható, hogy nem képeznek homogén csoportot, hanem jól láthatóan elkülönülnek egymástól. Az ALSCAL modell által kirajzolódott dimenziók alátámasztják, hogy külön csoportot alkotnak az egyedi élelmiszerek, valamint a készételek és a mindenmentes vásárolt termékek vásárlási tudatosságával kapcsolatos fogyasztói értékek.

A következő szakaszban a változók a klaszterelemzés segítségével csoportokba kerültek. Bár az ALSCAL tulajdonképpen a hasonló fontossággal bíró változókat ábrázolja grafikus formában, a nem-hierachikus klaszterelemzés is megerősített.

Amíg az előző kérdéseknél a vásárlói típusok 1-7 terjedő skálán értékelték a megadott állításokat, addig a következő fázisban a vásárlók saját sorrend felállításával választhatták ki, melyik álítás jellemző rájuk leginkább az élelmiszervásárláskor.

A felsorolt tíz állítás közül az egyéni sorrend felállításával ellenőrzésképpen a feldolgozást k-középpontú klaszterező eljárás is bevonásra került, a klaszterek számát 3-nak meghatározva. A k-klaszterező eljárással is hasonlóképpen érhetőek el a csoportok, így bizonyossá válik az eredmény megbízhatósága (3. táblázat).

3. TÁBLÁZAT

TABLE 3

\section{A vásárlói tudatosság klasztereinek meghatározása (Final Cluster Centre of Consumer Awareness Profile)}

\begin{tabular}{|c|c|c|c|}
\hline $\begin{array}{c}\text { P2- A következő kérdésnél arra vagyunk kíváncsiak, hogy } \\
\text { melyik állítás jellemző Önre élelmiszervásárláskor (In the } \\
\text { next questions, we are curious as to which statement is } \\
\text { typical for you when buyingfood) }\end{array}$ & $\begin{array}{l}\text { Trendi } \\
\text { (Trendy) } \\
\mathbf{N}=50\end{array}$ & $\begin{array}{l}\text { Tudatos } \\
\text { (Conscious) } \\
\mathbf{N}=92\end{array}$ & $\begin{array}{l}\text { Hagyományos } \\
\text { (Traditional) } \\
\quad \mathrm{N}=42\end{array}$ \\
\hline Etikus gyártási folyamatok (Ethical production processes) & 5,78 & 8,76 & 5,60 \\
\hline $\begin{array}{l}\text { Egyedi terméket jellemző információ a vállalatról, termékról (Specific } \\
\text { information about the company and product) }\end{array}$ & 5,84 & 7,92 & 6,88 \\
\hline $\begin{array}{l}\text { Környezettudatosság, környezetbarát eljárás (Environmentally } \\
\text { conscious, environmentally friendly) }\end{array}$ & 4,96 & 7,54 & 4,62 \\
\hline Újdonság varázsa, kiváncsiság (The charm of novelty, curiosity) & 9,48 & 6,42 & 4,95 \\
\hline Eredet, ország (made in) (Origin, country (made in)) & 4,90 & 6,24 & 7,55 \\
\hline Márka (Brand) & 7,70 & 4,97 & $\mathbf{8 , 3 3}$ \\
\hline Egészségtudatosság (Health Awareness) & 2,22 & 4,23 & 2,48 \\
\hline Megszokás, rutin (Routine) & 7,82 & 3,89 & 7,33 \\
\hline Ár (Price) & 3,50 & 2,95 & 4,98 \\
\hline Minőség (Quality) & 2,80 & 2,08 & 2,29 \\
\hline
\end{tabular}

Forrás (Source): Saját szerkesztés (Own compilation) 
A Trendik (K1=50 fó) csoportjának fó üzenete, hogy vásárlásaik során leginkább az újdonságok iránt nyitottak $(9,48)$, de a magas rutin $(7,82)$ vásárlási preferencia alapján ez a fajta nyitottság nem terjed ki az élelmiszerekkel szembeni egészségtudatosságra $(2,22)$, sem azok minőségi jellemzőjére $(2,8)$, sem pedig az árra $(3,5)$.

Az újdonság varázsa és az egyedi termékjellemző sokkal inkább motiváló tényezők a Trendi vásárlóknál, amelyek jól ismert márka, jól kommunikált brand képében jelennek meg számukra. Az egyes brandek iránti elköteleződés $(7,70)$ mellett sokat segít a klasztertagok mindennapi vásárlásaiban a rutinból való döntés $(7,82)$. Ezeknek a vásárlóknak a fenntarthatósági preferenciái az élelmiszergyártó vállalatok által megírt, a terméken kommunikált környezettudatosság és az etikus folyamatok $(5,78)$ irányában mozdulhat el. Az etikusság ezen formája azonban csak közepes fenntarthatósági elköteleződéshez elegendő. Jó tudni azonban, hogy a Trendik klasztere a brandeken keresztül jól edukálható, meggyőzhetőek és a fenntarthatósági szempontok megismerésére érzékenyek, amelyeket akár mindennapi alkalmazására, felhasználására is elsajátítanak (csomagolóanyagok, visszaváltás, szívószálmentes szerviz).

Jelen kutatás válaszadóinak legnagyobb számát (K2=90 fó) a Tudatos klaszter vásárlói alkotják. Jellemző rájuk, hogy kiemelten magas az etikus gyártási $(8,76)$ folyamatok iránti érzékenységük, valamint környezettudatosságuk
$(7,54)$. Ez a fajta nyitottság azonban meglepő módon nem kapcsolódik a saját egészségük $(4,23)$ tudatos fenntartására, megóvására. A Trendik és Tudatos klaszter vásárlói nem ár és minőség érzékeny vásárlók. Hasonlóan a Trendikhez, a Tudatos klaszter vásárlói is nyitottak az újdonságokra $(6,42)$, de a termék kommunikációban leginkább a termékjellemzőkre fókuszálnak. Mivel nem rutinból, hanem meggyőződésből vásárolnak, nem minden brand tudja megszólítani őket, ahogy az ország eredete sem jelent különösebb elköteleződést számukra az élelmiszerek vásárlásakor, hiszen az egyedi termékjellemzőkre építi bevásárlólistáját.

A Tradicionális klaszter $\left(\mathrm{K}_{3}=42\right.$ fó) vásárlói összehasonlítva az előző klaszterekhez képest jóval hagyományosabb vonalat és kiemelten erős árérzékenységet $(4,98)$ képviselnek. Érdeklődnek ugyan a márkák iránt és az újdonságokra is nyitottak, de az ár mellett erős az ország és ered iránti tudatosságuk $(7,55)$ vásárláskor. A Tradicionális klaszter vásárlóinak prioritásában nem áll élen a minőség $(2,23)$, a környezet- $(4,62)$ és egészségtudatosság $(2,48)$ iránti elköteleződés, és döntéseiket az etikus gyártási folyamatok közepesen befolyásolják hasonlóan a Trendikhez - az élelmiszerek vásárlásakor. A napi rutin és a megszokás vezeti őket az élelmiszerek kiválasztásában és nagy segítséget jelent számukra, ha ez érthetően van kommunikálva. A vásárlói tudatosság klasztereinek összehasonlítása a 2. ábrán látható. 
2. ÁBRA

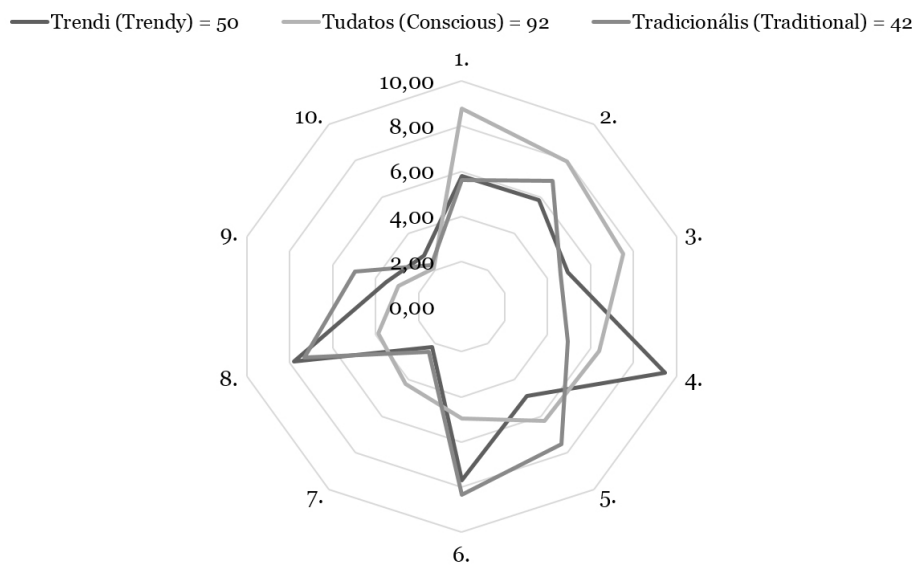

FIG. 2

\section{A vásárlói tudatosság klasztereinek összehasonlítása} (Chusters of Consumer Awareness)

Forrás (Source): Saját szerkesztés (Own compilation)

Megjegyzés (Notes):

1. Etikus gyártási folyamatok (Ethical production process); 2. Egyedi terméket jellemző információ a vállalatról, termékről (Specific information about the company and product); 3. Környezettudatosság, környezetbarát eljárás (Environmentally conscious, environmentally friendly); 4. Újdonság varázsa, kiváncsiság (The charm of novelty, curiosity); 5 . Eredet, ország (Origin, country (made in)); 6. Márka (Brand); 7. Egészségtudatosság (Health Awareness); 8. Megszokás, rutin (Routine); 9. Ár (Price); 10. Minőség (Quality)

\section{KöVETKEZTETÉSEK - CONCLUSIONS}

A földrajzi árujelzők, mint a regionális fenntarthatóság biztosítására létrejött minősítő rendszer részei azt kívánják meg, hogy a jelen és jövő generációk létfeltételeihez szükséges természeti és épített környezet minőségét, értékeit megőrizze úgy, hogy közben az adott rendszeren belül ne mondjon le sem a gazdasági fejlődés, sem a társadalmi egyenlőség és igazságosság igényeiről.

A cikk az uniós árujelzős élelmiszerek észlelését, egyrészt, mint intézményileg tanúsított minőségi címke mögött meghúzódó társadalmi értéket, másrészt az egyéni viselkedést befolyásoló, értékrendszert vizsgálta.

Annak ellenére, hogy az élelmiszer központi szerepet tölt be az emberi lét fenntartásában, a fogyasztók általában nagyon keveset tudnak arról, hogy a vásárolt termék honnan származik, milyen környezeti és társadalmi költségekkel és hatásokkal jár az elkészítésük vagy fogyasztásuk.

A teljes globális élelmiszerrendszerek kör- nyezeti hatásainak nyomonkövetése összetett és komplex folyamat. Egy vásárló számára annak megértése, hogy milyen lépésekre van szükség a rendszer fenntarthatóságának biztosításához és változást indítson el, ahhoz hatalmas ismeretanyagra van szüksége.

Az online - nem reprezentatív - kutatás eredményeiból mégis az állapítható meg, hogy a megkérdezettek körében a megszokásból, a rutinból történő vásárlások sokkal erősebbek, mint a minőség iránti, az országeredetet szem előtt tartó és a kockázati tényezők tudatosságából eredő értékek. A vásárlók saját egészsége, a környezet iránti elköteleződések vagy éppen a morális, etikai kérdések sem képviselnek fontos értéket élelmiszervásárlás során. Az értéktérképen lévő távolságok, mint vásárlói elutasítások, nemcsak földrajzilag, de mentálisan is elválasztja az eltérő értékek képviselőket.

Bár elméletileg a napjaink kereskedelmét meghatározó kereskedelmi formák sokkal tudatosabb, funkcionálisabb és pragmatikusabb vásárlási szokásokat hoztak magukkal, megfigyelhető, hogy a fogyasztók bizonyos termékkategóriákban tudatosabban viselkednek, mint 
másokban. Ott, ahol magas a vásárlással kapcsolatos észlelt kockázat ott inkább az ár és a minőség összehasonlítása alapján döntenek, míg előfordulhat, hogy egy másik vásárlási szituációban, vagy egy másik termékkategóriában, hajlamosabbak elcsábulni un. impulzusvásárlás irányába.

Azt, hogy egy vásárló hogyan csökkentheti az élelmiszerrendszer méltányosságát sértő környezeti hatásokat, hogyan ismerheti fel az élelmiszerek származásának igazolását; hogyan léphet fel az élelmiszerhamisítás elleni küzdelemben és, hogyan feleljen meg az egészségügyi és táplálkozási céloknak, olyan komplex kérdések, amelyek megnehezítik az élelmiszerekkel kapcsolatos információk hatékony észlelését. Mivel hosszú időbe telik a források azonosítása, vélhetőleg a nem azonosítható előállított élelmiszer többsége elveszti értékét az ellátási láncban a vásárlók nem észlelése miatt.

A cikkben a földrajzi árujelző, mint közjó vizsgálata egyrészt a minőség, másrészt az egészség, harmadrészt a kulturális örökség bizalmi kategóriáján keresztül került megvilágítás alá.

A vásárlói értékek feltárása azért fontos, mert az értékalapú konfliktusokhoz vezetnek. Értékalapú konfliktus kétféle módon keletkezik: ha az egyik fél - nem feltétlenül szándékosan - rá akarja kényszeríteni az értékrendjét a másikra; vagy ha valaki úgy érzi, hogy az adott környezetben nem tud az értékrendjének megfelelően cselekedni. Az értékalapú konfliktusok, azért jelentenek problémát, mert a konfliktus tárgyában, de a konfliktusmegoldás módjában sem értenek egyet a résztvevők.

Amennyiben azonban az értékeket támogató környezet pozitívan hat a termékre, akkor a hasonló értékrend rokonszenvet és elköteleződést, elégedettséget vált ki.

A kulturális örökség (cultural patrimony), alapvető fontosságú egy nép vagy nemzet története szempontjából, a csoport értékeinek és kollektív identitásának megerősítéséhez, tükrözéséhez és befolyásolásához kötődik (HOFFMAN, 2006), viszont fontos megjegyezni, hogy a kulturális örökség nem egy nép tulajdonában van; hanem inkább az önállóan meghatározott kollektív állampolgárságot képviseli.

A gasztronacionalizmus viszont egy olyan szélesebb identitásprojekt része, amely Európa-szerte és a világban egyre inkább kibontakozóban van, és amely azokra az értékekre fókuszál, amelyeket a globális lépések felgyorsítanak, és amelyekre a nemzeti termelésre esetlegesen veszteségekkel reagál (DOBBIN et al., 2007).

A magyar értéktérkép alapján jelenleg sem az egyéni, de az intézményes kultúra sem teljesen alkalmas arra, hogy a globális paradoxonok adta helyzetekre rugalmasan reagáljon, és a hátrányokat időben kompenzálja, ezért egyre több alternatív és hibrid életmodell jelenik meg helyi és a nemzetközi értékek elfogadása és választása, illetve elérhetősége mentén.

$\mathrm{Az}$ integritásra épülő uniós gazdaság és társadalom esetében ezeknek a különböző értékeknek tudatos vagy nem tudatos elkülönülése és szétválasztása, komoly kihívást jelentenek fenntarthatósági szempontból nemcsak a jelen, de a jövő társadalom számára is. A vásárlók mindennapi döntéseiben egy termék iránti gyenge elkötelezettség láthatóan gyakran összefonódik más jelenségekkel. A származási hely, mint érték bizonyos kötelezettségvállalási értéket adhat a vásárlóknak, de ennek gyenge ereje jelenleg még nem teszi lehetővé, hogy segítse a termelők és a kiskereskedelmi láncok közötti koordinációt. Viszont amennyiben az együttmúködés ismétlődővé válik, az elemzés azt sugallja, hogy a gyenge elkötelezettség fontos szerepet játszhat az együttmúködés előmozdításában.

A cikk újszerűsége minden bizonnyal az, hogy módszertanilag integratív kutatási szempontokat szem előtt tartva a földrajzi árujelzők vizsgálatához különböző módszertani elveket vont össze. Ezzel az interdiszciplinaritás elvét szem előtt tartva a korábbi egyoldalú értelmezéseket korrigálta, hogy egyes márkaértékek észlelése a jelen piaci körülmények között is alkalmazhatóak legyenek. 


\section{IRODALOMJEGYZÉK - REFERENCES}

Appadurai, A.: Is homo hierarchicus? American Ethnologist. Wiley. 1986. 13 (4) 745-761. http://dx.doi.org/10.1525/ ae.1986.13.4.02a00090

Bakacsi, G.: A szervezeti magatartás alapjai. Aula Kiadó, Budapest, 2010.

Bauer, A. - Berács, J.: A marketing alapjai. Aula Kiadó, Budapest, 2007.

Billig, M.: Banal Nationalism. London, UK: Sage. 8. 1995.

Brubaker, R.: Nationalism Reframed: Nationhood and the National Question in the New Europe. Cambridge, UK: Cambridge University Press, 1996. https:// doi.org/10.1017/CBO9780511558764

Brundtland, G. H.: Közös Jövőnk. A környezet és fejlesztés világbizottság jelentése. Budapest, 1988.

Calhoun, C.: Nations Matter: Culture, History, and the Cosmopolitan Dream. London, UK: Routledge, 2007. https:// doi.org/10.4324/9780203960899

Csutora, M. - Kerekes, S.: A környezetbarát vállalatirányítás eszközei. KJK Kiadó, Budapest, 2004.

Daly, H. E. - Cobb, J. B.: Forthe Common Good. Redirecting the Economy. 1989.

Dobbin, F. - Simmons, B - Garrett, G.: The Global Diffusion of Public Policies: Social Construction, Coercion, Competition, or Learning? Annual Review of Sociology. Annual Reviews. 2007. 33 (1) 449-472. http://dx.doi.org/10.1146/ annurev.soc.33.090106.142507

Ericksen, P. J.: Conceptualizing Food Systems for Global Environmental Change Research. Global Environmental Change. 2008. 18 (1) 234-245. http://dx.doi. org/10.1016/j.gloenvcha.2007.09.002

Ericksen, P. J.: Conceptualizing Food Systems for Global Environmental Change Research. Global Environmental Change. Elsevier BV. 2008. 18 (1) 234-245. http://dx.doi.org/10.1016/j. gloenvcha.2007.09.002
Feather, P. - Hellerstein, D. - Hansen, L.: Economic Valuation of Environmental Benefits and the Targeting of Conservation Programs: The Case of the CRP. Economic Research Service AER. 778. 1999.

Fiddes, N.: Meat In Change: Rural and Urban Cases. Meat in Change: Rural and Urban Cases. 1990. 230-253.

Foley, J. A. - Ramankutty, N. - Brauman, K. A. - Cassidy, E. S. - Gerber, J. S. - Johnston, M. - Balzer, C.: Solutions for a Cultivated Planet. Nature. 2011. 478 (7369) 337. http://dx.doi.org/10.1038/ nature 10452

Friedmann, H. - McMichael, P.: Agriculture and the State System: The Rise and Decline of National Agricultures, 1870 to the Present. Sociologia Ruralis, 1989. Wiley. 1989. 29 (2) 93-117. http://dx.doi. org/10.1111/j.1467-9523.1989.tboo36o.x

Friedmann, H.: The Political Economy of Food: A Global Crisis. New left review. 1993. (197) 29-57. http://dx.doi. org/10.2190/451a-896w-gglk-elxt

Füstös, L. - Kovács, E.: A számítógépes adatelemzés statisztikai módszerei Tankönyvkiadó. Budapest, 1989.

Granovetter, M.: The Strength of Weak Ties: A Network Theory Revisited. Sociological Theory. 1983. 201-233. http://dx.doi. org/10.2307/202051

Granovetter, M.: Economic Institutions as Social Constructions: A Framework for Analysis. Acta sociologica. 1992. $35 \quad$ (1) 3-11. http://dx.doi. org/10.1177/000169939203500101

Goodman, D.: The Quality 'Turn' and Alternative Food Practices: Reflections and Agenda. Journal of Rural Studies. 2003. 19 (1) 1-7. http://dx.doi.org/10.1016/s07430167(02)00043-8

Hoffman, B. T. (Ed.): Art and Cultural Heritage: Law, Policy and Practice. Cambridge University Press Cambridge U.K. 2006.

Hofmeister-Tóth, Á.: Fogyasztói magatartás, Aula Kiadó, Budapest, 2003. 
Hofmeister-Tóth, Á. - Simon, J. Sajtos, L.: A fogyasztói elégedettség. Alinea Kiadó, Budapest, 2003.

Juhász, A. (szerk.): Piaci erőviszonyok alakulása a belföldi élelmiszerpiac szereplői között. Agrárgazdasági Tanulmányok 2005/3. szám, Agrárgazdasági Kutató Intézet, Budapest, 2005.

Keating, M.: 'European Integration and the Nationalities Question.' Politics \& Society. 2004. 32 367-388. https://doi. org/10.1177/0032329204267295

Kolos, K.: A kockázat szerepe a fogyasztók vásárlási döntéseiben. Marketing \& Menedzsment. 1997. 31 (5) 67-73.

Kotler, P.: A Generic Concept of Marketing. Marketing Management. 1998. 7 (3) 48.

Kruskal, J. B. - Wish, M.: Multidimensional Scaling. Number 07-011 in Sage University Paper Series on Quantitative Applications in the Social Sciences. 1978. https://doi. org/10.4135/9781412985130

Langinier, C. - Babcock, B. A.: Agricultural Production Clubs: Viability and Welfare Implications. Journal of Agricultural \& Food Industrial Organization. 2008. 6 (1) http://dx.doi.org/10.2202/15420485.1187

Lehota, J.: Marketingkutatás az agrárgazdaságban. Mezőgazda Kiadó, Budapest, 2001.

Lewis, D. - Bridger, D.: The Soul of the New Consumer Nicholas Brealey Publishing, London, 2000.

Liverman, D. - Kapadia, K.: Food Systems and the Global Environment: An Overview. Food Security And Global Environmental Change. 1. 2010.

Nemesicsné Zsóka, Á.: Consistency and Gaps in Pro-Environmental Organisational Behaviour (Doctoral dissertation, Ph.D. dissertation). Budapest Corvinus Egyetem, 2005.

Nilson, T. H.: Value-Added Marketing: Marketing Management for Superior Results. McGraw-Hill Book Company. 1992.
Pallóné Kisérdi, I.: A versenyképesség biztosításának új minőségi dimenziója az élelmiszergazdaságban EU csatlakozásunk szempontjából. Doktori Disszertáció, Budapesti Corvinus Egyetem, 2003

Panyor, Á.: Különleges élelmiszerek piacnövelési lehetőségei megkérdezések tükrében. Doktori Disszertáció, Budapesti Corvinus Egyetem, 2007.

Popovics, A.: A földrajzi helyhez kapcsolódó és a hagyományos magyar termékek lehetséges szerepe az élelmiszerfogyasztói magatartásban. Doktori Disszertáció, Szent István Egyetem, Gödöllő, 2009.

Schaltegger, S. - Burritt, R. - Petersen, H.: $\quad$ Corporate Environmental Management: Striving for Sustainability. Sheffield, Greenleaf. 2003.

Somers, M. R. - Block, F.: From Poverty to Perversity: Ideas, Markets, and Institutions over 200 Years of Welfare Debate. American Sociological Review. SAGE Publications. 2005. 70 (2) 260-287. http://dx.doi. org/10.1177/000312240507000204

Spedding, C. R.: Agriculture and the Citizen. Chapman \& Hall Ltd., 1996.

Szakály, Z. - Pallóné, K. I. - Nábrádi, A.: Marketing a hagyományos és tájjellegü élelmiszerek piacán. Kaposvár: Kaposvári Egyetem Gazdaságtudományi Kar. 2010.

Tregear, A.: The Activities and Experiences of Speciality Regional Food Producers in Northern England: A Qualitative Study. In 67th Seminar, October 28-30, 1999, LeMans, France (No. 241119). European Association of Agricultural Economists. 1999, October

Young, F. W. - Hamer, R. M. (ed.): Multidimensional Scaling: History, Theory, And Applications. Hillsdale, Lawrence Erlbaum Associates New York, 1987. 
JEGYZETEK $\nRightarrow$ NOTES 